\title{
Design and Two New Indol-Steroid Derivatives to Evaluate their Theoretical Activity Against Protein Kinase 2 (CK2) Protein
}

\author{
Rosas-Nexticapa Marcela ${ }^{1, *(\mathbb{D})}$, Figueroa-Valverde Lauro ${ }^{2, *}{ }^{\mathbb{D}}$, Díaz-Cedillo Francisco ${ }^{3}{ }^{\mathbb{D}}$, López-Ramos \\ Maria $^{2}{ }^{(\mathbb{D})}$, Mateu-Armad Maria Virginia ${ }^{1(\mathbb{D})}$, Garcimarrero E. Alejandara ${ }^{1(\mathbb{D})}$, \\ Cauich-Carrillo Regina 2 (D) \\ 1 Facultad de Nutrición, Universidad Veracruzana, Médicos y Odontologos s/n C.P. 91010, Unidad del Bosque Xalapa \\ Veracruz, México \\ 2 Laboratory of Pharmaco-Chemistry, Faculty of Chemical Biological Sciences, University Autonomous of Campeche, Av. \\ Agustín Melgar s/n, Col Buenavista C.P. 24039 Campeche, Camp., México \\ 3 Escuela Nacional de Ciencias Biológicas del Instituto Politécnico Nacional. Prol. Carpio y Plan de Ayala s/n Col. Santo \\ Tomas, D.F. C.P. 11340, México \\ * Correspondence: lfiguero@uacam.mx; lauro_199@yahoo.com;
}

Scopus Author ID 55772714800

Received: 27.04.2020; Revised: 23.05.2020; Accepted: 24.05.2020; Published: 27.05.2020

\begin{abstract}
Several compounds have been developed to evaluate their interaction with CK2-protein surface using some docking models. The objective of this investigation was to prepare two indol-steroid derivatives from $6 \beta$-nitroprogesterone using some chemical strategies. In addition, the interaction of both compounds 3 and 6 with CK2-protein was evaluated in a docking model using quinalizarin as tool. The results showed that either compounds 3 or 6 have a higher affinity by 3FL9 protein surface compared with quinalizarin. In conclusion, this phenomenon suggests that either compounds 3 or 6 could exert changes in the biological activity of CK2 protein.
\end{abstract}

Keywords: Indole; steroid; derivative; $6 \beta$-nitroprogesterone; CK2-protein.

(C) 2020 by the authors. This article is an open-access article distributed under the terms and conditions of the Creative Commons Attribution (CC BY) license (https://creativecommons.org/licenses/by/4.0/).

\section{Introduction}

Cancer is a main risk factor of death worldwide $[1,2]$; it is noteworthy that some data suggest that protein kinase 2 (CK2) may be related to several types of cancer [3, 4]. For example, some studies showed that CK2 might produce indirectly neoplastic growth through oncogenes activation $[5,6]$. Other data showed that CK2 could be involved in some mutations of the cell division cycle via CDC37 (co-chaperone) activation [7]. Another study showed that CK2 could increase breast cancer through nuclear factor- $\kappa \mathrm{B}$ phosphorylation [8]. Furthermore, a report indicates that $\mathrm{CK} 2$ can regulate Wnt signaling pathways, increasing transcriptional activity; in this way, CK2 can phosphorylating some biological target such as Dvl-protein [9], $\beta$-catenin [10], TCF/LEF transcription factors [11] which could be involved in an oncogenesis process [12-14].

On the other hand, to decrease the biological activity of CK2 in patients with cancer have used several CK2- inhibitors such as benzimidazole [15], TBB (4,5,6,7-tetrabromo-2azabenzimidazole) [16], heparin [17], emodin [18], quinalizarin [19]. Here, it is essential to mention that several compounds have been developed as CK-inhibitors; for example, the preparation of 5-anilinopyrazolo[1,5-a]pyrimidine from 7-oxetan-3-yl amino derivative to 
evaluate their biological activity against CK2 in vitro [20]. In addition, a 3-cyano-5-aryl-7aminopyrazolo[1,5-a]pyrimidine was prepared, which showed biological activity against CK2 in HCT-116 cells [21]. Other data showed the synthesis of a pyrroloquinoxaline as CK2inhibitor on immature lymphocytes [22].

To evaluate the biological activity of several compounds against CK2 a series of theoretical studies have be carried out. For example, a report showed the pharmacophore identification and validation study for some CK2-inhibitors using the CoMFA and CoMSIA methods [23]. Other data showed the preparation of a pharmacophore model for an Indeno[1,2b]indole derivative as a human protein kinase CK2 Inhibitor using MOE software [24]. Additionally, a study showed the identification of some pharmacophore for CK2 inhibitors using a Bayesian model [25]. Other reports showed the pharmacophore generation for some CK2-inhibitors using LigandScout software [26]. Recently, a pharmacophore was prepared to evaluate the interaction of a steroid derivative with CK2-protein using the LigandScout software [27]. All these data suggest the preparation of several CK2-inhibitors; however, the interaction of some drugs with CK2-protein is very confusing, perhaps this phenomenon could be due to; (1) differences in the chemical structure of each drug; or (2) to different methods used in each theoretical experimental. Analyzing all these data, the objective of this investigation was to prepare two indol-steroid derivatives to evaluate their interaction with CK2-protein, a docking model.

\section{Materials and Methods}

\subsection{General methods.}

$6 \beta$-nitroestrone (compound 3) was prepared using a previously method reported [28]. The other reagents used in this investigation were acquired from Sigma-Aldrich Co., Ltd. The melting point for compounds was evaluated on an Electrothermal (900 model). Infrared spectra (IR) were evaluated with a Thermo Scientific iSOFT-IR spectrometer. ${ }^{1} \mathrm{H}$ and ${ }^{13} \mathrm{C}$ NMR spectra were recorded using a Varian VXR300/5 FT NMR spectrometer at $300 \mathrm{MHz}$ in $\mathrm{CDCl}_{3}$ using TMS as internal standard. EIMS spectra were obtained with a Finnigan Trace Gas Chromatography Polaris Q-Spectrometer. Elementary analysis data were acquired from a Perkin Elmer Ser. II CHNS/02400 elemental analyzer.

\subsection{Synthesis of a steroid-pirrol derivative.}

\section{1-[(3aS,6S)-6-ethyl-3-[1-(3-ethynylphenyl)-5-phenyl-2,3-dihy-dropyrrol-4-yl]-3a,6-dime- thyl-2,3,4,5,5a,7,8,9,9a,9b-decahy-dro-1H-cyclopenta[a]naphthalen-7-yl]propan-2-one} (2)

In a round bottom flask $(10 \mathrm{ml})$, progesterone $(200 \mathrm{mg}, 0.64 \mathrm{mmol})$, 3-ethynylaniline (100 $\mu$ l, $0.90 \mathrm{mmol})$, Copper(II) chloride, iodine (170 mg, $0.67 \mathrm{mmol})$ and $5 \mathrm{ml}$ of dimethyl sulfoxide were stirred at reflux for $12 \mathrm{~h}$. Then, the solvent was evaporated under reduced pressure and following the product was purified via crystallization using the methanol:hexane:water (4:2:1) system; yielding $60 \%$ of product; m.p. $70-72{ }^{\circ} \mathrm{C}$; IR $\left(V_{\max }, \mathrm{cm}^{-}\right.$ 1) 2110 and 1712: ${ }^{1} \mathrm{H}$ NMR $\left(300 \mathrm{MHz}, \mathrm{CDCl}_{3}-d\right) \delta_{\mathrm{H}:} 0.58(\mathrm{~s}, 3 \mathrm{H}), 0.86(\mathrm{~s}, 3 \mathrm{H}), 1.10-1.82(\mathrm{~m}$, 13H), 2.08-2.82 (m 6H), 2.88 (s, 1H), 2.94 (m, 1H), 2.98 (m, 1H), 3.02-4.04 (m, 3H), 4.94 (d, $1 \mathrm{H}, \mathrm{J}=1.90 \mathrm{~Hz}), 6.88-7.48(\mathrm{~m}, 8 \mathrm{H}) \mathrm{ppm} .{ }^{13} \mathrm{C} \mathrm{NMR}\left(300 \mathrm{~Hz}, \mathrm{CDCl}_{3}\right) \delta \mathrm{c}: 12.42,19.06,21.32$, $24.60,25.59,31.27,32.00,32.62,37.15,37.34,37.50,38.06,42.83,46.92,48.36,53.44$, $56.22,56.44,78.22,84.00,117.22,122.62,123.41,123.59,126.94,127.22,128.00$, 
129.00, 129.16, 129.80, 130.94, 138.66, 143.40, 145.20, 208.90 ppm. EI-MS m/z: 515.31. Anal. Calcd. for $\mathrm{C}_{37} \mathrm{H}_{41}$ NO. C, 86.17; H, 8.01; N, 2.72; O, 3.10. Found: C, 86.14; H, 8.00.

2.3. Synthesis of an indol-steroid-pentacosa derivative.

\section{(1S,22S)-21-[1-(3-ethynylphenyl)-5-phenyl-2,3-dihydropyrrol-4-yl]-1,22-dime- thyl-10-azahexacyclo[12.11.0.03,12.04,9.017,25.018,22]pentacosa-3(12),4(9),5,7-tetraene} (3)

In a round bottom flask $(10 \mathrm{ml})$, compound $2(200 \mathrm{mg}, 0.39 \mathrm{mmol})$ phenylhydrazine $(50 \mu 1,0.50 \mathrm{mmol})$, and $5 \mathrm{ml}$ of acetic acid were stirred at reflux for $12 \mathrm{~h}$. Then, the solvent was evaporated under reduced pressure and following the product was purified via crystallization using the methanol:water (4:1) system; yielding $55 \%$ of product; m.p. $80-82^{\circ} \mathrm{C}$; IR $\left(V_{\max }, \mathrm{cm}^{-1}\right) 3410$ and 2112: ${ }^{1} \mathrm{H}$ NMR $\left(300 \mathrm{MHz} \mathrm{CDCl}_{3}-d\right) \delta_{\mathrm{H}}: 0.58(\mathrm{~s}, 3 \mathrm{H}), 1.00(\mathrm{~s}, 3 \mathrm{H})$, $1.12-1.82(\mathrm{~m}, 12 \mathrm{H}), 2.04-2.46(\mathrm{~m}, 4 \mathrm{H}), 2.88(\mathrm{~s}, 1 \mathrm{H}), 2.94-3.02(\mathrm{~m}, 2 \mathrm{H}), 3.62-3.70(\mathrm{~m}, 2 \mathrm{H})$, 3.98-4.04 (m, 2H), $5.42(\mathrm{~d}, 1 \mathrm{H}, \mathrm{J}=1.90 \mathrm{~Hz}), 6.88-6.98(\mathrm{~m}, 2 \mathrm{H}), 7.12(\mathrm{~m}, 1 \mathrm{H}), 7.14-7.20(\mathrm{~m}$, $3 \mathrm{H}), 7.22-7.42(\mathrm{~m}, 3 \mathrm{H}), 7.44-7.48(\mathrm{~m}, 4 \mathrm{H}), 7.80$ (broad, $1 \mathrm{H}) \mathrm{ppm} .{ }^{13} \mathrm{C} \mathrm{NMR}\left(300 \mathrm{~Hz}, \mathrm{CDCl}_{3}\right)$ $\delta_{\mathrm{C}}: 12.42,18.34,21.12,22.40,24.62,25.59,31.27,31.84,32.22,34.12,38.06,40.54$, 42.80, 46.92, 52.36, 56.22, 56.44, 78.22, 84.02, 111.42, 111.62, 117.22, 117.43, 118.50, $119.00,120.96,123.41,123.59,126.98,127.16,128.00,128.14,129.00,129.16,129.80$, 130.96, 134.12, 136.44, 143.36, 143.76, 145.20 pp. EI-MS m/z: 588.35. Anal. Calcd. for $\mathrm{C}_{43} \mathrm{H}_{44} \mathrm{~N}_{2}$. C, 87.71; H, 7.53; N, 4.76. Found: C, 87.70; H, 7.50.

\subsection{Synthesis of an indol-steroid-pentacosa derivative.}

(10R,13S,17S)-17-[1-(3-ethynylphenyl)-5-phenyl-2,3-dihy-dropyrrol-4-yl]-10,13dime-thyl-6-nitro-1,2,4,7,8,9,11,12,14, 15,16,17-dodecahydrocyclopenta[a]phenanthren3-one (5)

In a round bottom flask $(10 \mathrm{ml}), 6 \beta$-nitroprogesterone $(200 \mathrm{mg}, 0.56 \mathrm{mmol}), 3$ ethynylaniline (100 $\mu 1,0.90 \mathrm{mmol})$, Copper(II) chloride, iodine $(170 \mathrm{mg}, 0.67 \mathrm{mmol})$ and $5 \mathrm{ml}$ of dimethyl sulfoxide were stirred at reflux for $12 \mathrm{~h}$. Then, the solvent was evaporated under reduced pressure and following the product was purified via crystallization using the methanol:hexane:water (4:1:1) system; yielding $58 \%$ of product; m.p. $138-140{ }^{\circ} \mathrm{C}$; IR $\left(V_{\max }\right.$, $\left.\mathrm{cm}^{-1}\right)$ 2110, 1712and 1538: ${ }^{1} \mathrm{H}$ NMR $\left(300 \mathrm{MHz}, \mathrm{CDCl}_{3}-d\right) \delta_{\mathrm{H}:} 0.56(\mathrm{~s}, 3 \mathrm{H}), 1.10(\mathrm{~m}, 1 \mathrm{H}), 1.20$ $(\mathrm{s}, 3 \mathrm{H}), 1.26-1.94(\mathrm{~m}, 11 \mathrm{H}), 2.10-2.60(\mathrm{~m}, 5 \mathrm{H}), 2.86(\mathrm{~s}, 1 \mathrm{H}), 2.90(\mathrm{~m}, 1 \mathrm{H}), 2.92-3.00(\mathrm{~m}, 2 \mathrm{H})$, 3.30-3.42 (m, 2H), 3.98-4.04 (m, 2H), 6.86-7.48 (m, 9H) ppm. ${ }^{13} \mathrm{C} \mathrm{NMR}\left(300 \mathrm{~Hz}, \mathrm{CDCl}_{3}\right) \delta_{\mathrm{C}}$ : $12.42,18.40,23.72,24.63,25.56,30.52,30.72,31.27,33.32,37.36,38.09,40.50,42.83$, $44.20,46.92,54.70,56.06,56.46,78.20,84.02,117.22,123.40,123.59,126.96,127.22$, $128.04,129.00,129.16,129.70,129.80,130.98,131.94,143.36,145.20,205.70$ ppm. EIMS m/z: 560.30. Anal. Calcd. for $\mathrm{C}_{37} \mathrm{H}_{40} \mathrm{~N}_{2} \mathrm{O}_{3}$. C, 79.25; H, 7.19; N, 5.00; O, 8.56. Found: C, $79.22 ; \mathrm{H}, 5.00$.

\subsection{Preparation of a nitro-indol-steroid derivative.}

(1R,5S,6S)-6-[1-(3-ethynylphenyl)-5-phenyl-2,3-dihydropy-rrol-4-yl]-1,5-dimethyl-12-nitro-16-azahexacyclo[11.11.0.02,10.05,9.015,23.017,22]tetracosa-12,15(23), 17(22),18,20-penta-ene (6)

In a round bottom flask $(10 \mathrm{ml})$, compound $5(200 \mathrm{mg}, 0.36 \mathrm{mmol})$ phenylhydrazine $(50 \mu \mathrm{l}, 0.50 \mathrm{mmol})$, and $5 \mathrm{ml}$ of acetic acid were stirred at reflux for $12 \mathrm{~h}$. Then, the solvent 
was evaporated under reduced pressure and following the product was purified via crystallization using the methanol:water (4:1) system; yielding 53\% of product; m.p. 172-174 ${ }^{\circ} \mathrm{C}$; IR $\left(V_{\max }, \mathrm{cm}^{-1}\right) 3412,2110$ and 1538: ${ }^{1} \mathrm{H}$ NMR $\left(300 \mathrm{MHz}, \mathrm{CDCl}_{3}-d\right) \delta_{\mathrm{H}}: 0.56(\mathrm{~s}, 3 \mathrm{H}), 0.98$ (m, 1H), $1.10(\mathrm{~s}, 3 \mathrm{H}), 1.22-1.92(\mathrm{~m}, 10 \mathrm{H}), 2.36-2.80(\mathrm{~m}, 7 \mathrm{H}), 2.86(\mathrm{~s}, 1 \mathrm{H}), 2.88(\mathrm{~m}, 1 \mathrm{H}), 2.92-$ $3.00(\mathrm{~m}, 2 \mathrm{H}), 3.10$ (broad, 1H), $3.30(\mathrm{~m}, 1 \mathrm{H}), 3.98-4.06(\mathrm{~m}, 2 \mathrm{H}), 4.80-6.70(\mathrm{~m}, 3 \mathrm{H}), 6.86-6.98$ $(\mathrm{m}, 2 \mathrm{H}), 7.00(\mathrm{~m}, 1 \mathrm{H}), 7.12-7.48(\mathrm{~m}, 8 \mathrm{H}) \mathrm{ppm} .{ }^{13} \mathrm{C} \mathrm{NMR}\left(300 \mathrm{~Hz}, \mathrm{CDCl}_{3}\right) \delta_{\mathrm{C}}: 12.42,19.96$, 23.70, 24.63, 25.59, 25.96, 30.22, 30.70, 31.27, 35.60, 38.09, 41.12, 42.80, 46.02, 46.90, $56.04,56.44,56.60,60.34,78.22,84.02,108.36,116.27,117.22,122.24,123.40,123.59$, $126.98,127.04,127.20,128.02$, 128.92, 129.00, 129.00, 129.16, 129.80, 130.84, 130.90, 130.98, 143.40, 145.20, 150.20 ppm. EI-MS m/z: 635.35. Anal. Calcd. for $\mathrm{C}_{43} \mathrm{H}_{45} \mathrm{~N}_{3} \mathrm{O}_{2}$. C, 81.23; H, 7.13; N, 6.61; O, 5.03. Found: C, 81.20; H, 7.10.

\subsection{Pharmacophore model.}

A pharmacophore for both compounds 3 and 6 were developed using LigandScout software [29].

\subsection{Protein-ligand interaction.}

The interaction of both compounds 3 and 6 with CK2-protein surface was evaluated using 3FL5-protein [30] as a tool. Furthermore, both Chimerax [31] and Achilles Blind Docking Server models [32] were used to calculate both binding energy and distance between amino acid residues of 3FL5-protein and both compounds 3 and 6 .

\subsection{Pharmacokinetics parameter.}

To evaluate some pharmacokinetic factors involved in the chemical structure of either compounds 3 or 6, the SwissADME software was used [33].

\section{Results and Discussion}

Have been prepared several compounds as CK2-inhibitors; however, some of the protocols use some reagents which are dangerous and require special conditions [15-22]. Also, the interaction with CK2 protein is very confusing; perhaps, this phenomenon could be to different structure chemical of each compound. Analyzing these data, in this investigation, two indol-steroid derivatives were synthesized to evaluate their interaction with $\mathrm{CK} 2$ protein using several strategies as follows.

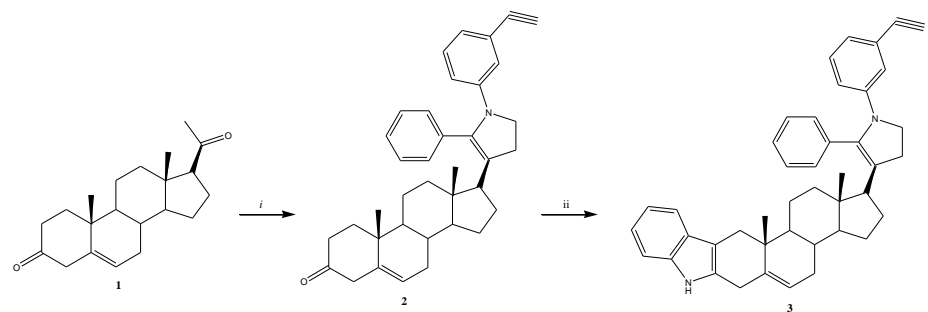

Figure 1. Synthesis of an indol-steroid-pentacosa derivative (3). Reagents and conditions: $i=$ progesterone, 3ethynylaniline, Copper(II) chloride, iodine, dimethyl sulfoxide; $i i=$ phenylhydrazine, acetic acid.

\subsection{Preparation of a steroid-pirrol derivative.}

There are some reports for preparation of pirrol derivatives using several reagents such as tetrakis(triphenylphosphine)palladium(0) [34], $\mathrm{K}_{2} \mathrm{~S}_{2} \mathrm{O}_{8} /(2,2,6,6 /$ Tetramethyl-1-pi-peridin- 
yloxy) [35], $\mathrm{Cu}(\mathrm{Oac})_{2}$ [36], phosphoric acid [37] and others. In this investigation, the synthesis of a steroid-pirrol derivative (compound 2) was prepared from progesterone, 3-ethynylaniline, acetone in the presence of dimethyl sulfoxide (Figure 1).

The ${ }^{1} \mathrm{H}$ NMR spectrum of 2 showed several signals at $0.58-0.86$ ppm for methyl groups bound to steroid nucleus; at 1.10-2.82, 2.98, and 4.94 ppm for steroid moiety; at $2.88 \mathrm{ppm}$ for alkyne group; at 2.94, 3.02-4.04 ppm for 2,3-Dihydro-1H-pyrrole ring; at 6.88-7.48 ppm for phenyl groups. Besides, the ${ }^{13} \mathrm{C}$ NMR spectra display chemical shifts at 12.42-19.06 ppm for methyl groups linked to steroid nucleus; at 21.32-25.59, 32.00-56.22, 122.62 and $138.66 \mathrm{ppm}$ for steroid moiety; at 31.27, 56.44, 129.16 and 143.20 ppm for 2,3-Dihydro-1H-pyrrole ring; at 78.22-84.00 ppm for alkyne group; at 117.22, 123.41-129.00, 129.80-130.94 and 145.20 ppm for phenyl groups. Additionally, the mass spectrum from 2 showed a molecular ion $(\mathrm{m} / \mathrm{z})$ 208.90 .

\subsection{Synthesis of an indol-steroid-pentacosa derivative.}

Several indol derivatives have been prepared using some reagents such as $\mathrm{CoCl}_{2} / \mathrm{Ag}_{2} \mathrm{CO}_{3} / \mathrm{Et}_{3} \mathrm{~N}$ [38], $\mathrm{Cu}(\mathrm{Oac})_{2} / 1,1$ '-Bis(diphenylphosphino)ferrocene [39], CuI/N,N'Dimethylethyl-enediamine [40], $\mathrm{Rh}_{2}(\mathrm{Oac})_{4}$ [41], tetramethyl thiourea [42] and others. In this study, the compound 2 reacted with phenylhydrazine in the presence of acetic acid to form indol-steroid-pentacosa derivative (3). The ${ }^{1} \mathrm{H}$ NMR spectrum of 3 (Figure 1) showed several signals at $0.58-1.00 \mathrm{ppm}$ for methyl groups bound to steroid nucleus; at 1.12-2.46, 3.62-3.70 and $5.42 \mathrm{ppm}$ for steroid moiety; at $2.88 \mathrm{ppm}$ for alkyne group; at 2.94-3.02 and 3.98-4.04 ppm for 2,3-Dihydro-1H-pyrrole ring; at 6.88-6.98, 7.14-7.20 and 7.44-7.48 ppm for phenyl groups; at 7.12, 7.22-7.42 ppm for indol ring. Besides, the ${ }^{13} \mathrm{C}$ NMR spectra display chemical shifts at 12.42-18.34 ppm for methyl groups linked to steroid nucleus; at 21.12-25.59, 31.84-56.22, 117.43 and $143.76 \mathrm{ppm}$ for steroid moiety; at 31.27, 56.44, 129.16 and $143.36 \mathrm{ppm}$ for 2,3Dihydro-1H-pyrrole ring; at 78.22-84.02 ppm for alkyne group; at 111.42-11.62, 118.50120.96, 128.14 and 134.12-136.44 ppm for indole ring; at 117.22, 123.41-128.00, 129.00, 129.80-130.96 and 145.20 ppm for phenyl groups. Finally, the mass spectrum from $\mathbf{3}$ showed a molecular ion $(\mathrm{m} / \mathrm{z}) 588.35$.

\subsection{Synthesis of a 2,3-dihydropyrrolyl-steroid-3-one derivative.}

The 2,3-dihydropyrrolyl-steroid-3-one analog was prepared from 6 $\beta$-nitroprogesterone, 3-ethynylaniline, Copper(II) in the presence of dimethyl sulfoxide (Figure 2).

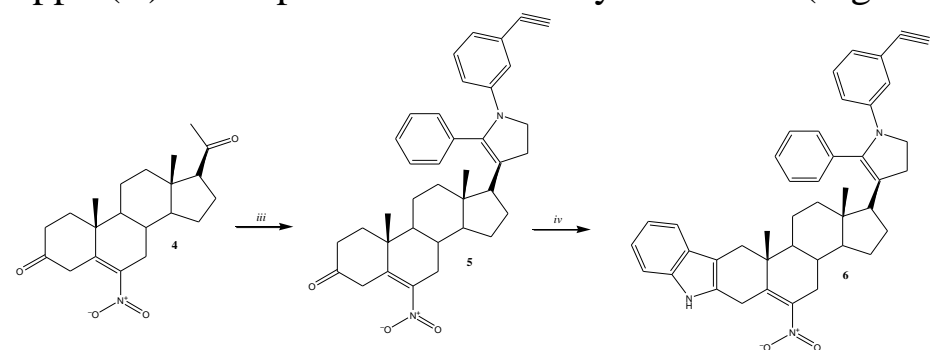

Figure 2. Preparation of a nitro-indol-steroid derivative (6). reagents and conditions: $i i i=6 \beta$-nitroprogesterone, 3-ethynylaniline, Copper(II) chloride, iodine, dimethyl sulfoxide; $i v=$ phenylhydrazine, acetic acid.

The ${ }^{1} \mathrm{H}$ NMR spectrum of 5 showed several signals at $0.56-1.20 \mathrm{ppm}$ for methyl groups bound to steroid nucleus; at 1.10, 1.24-1.94, 2.10-2.60, 2.90 and 3.30-3.42 ppm for steroid moiety; at $2.86 \mathrm{ppm}$ for alkyne group; at 2.92-3.00 and 3.98-4.04 ppm for 2,3-Dihydro-1H- 
pyrrole ring; at 6.86-7.48 ppm for phenyl groups; at 7.12, 7.22-7.42 ppm for indol ring. Also, the ${ }^{13} \mathrm{C}$ NMR spectra display chemical shifts at $12.42-18.40 \mathrm{ppm}$ for methyl groups linked to steroid nucleus; at 23.72-30.72, 33.32-56.06, 129.70 and 131.94 ppm for steroid moiety; at $31.27,56.46,129.16$ and 143.36 ppm for 2,3-Dihydro-1H-pyrrole ring; at 78.20-84.02 ppm for alkyne group; at 117.22-129.00, 129.80-130.98 and 145.20 ppm for phenyl groups; at 205.70 ppm for ketone group. In addition, the mass spectrum from 5 showed a molecular ion $(\mathrm{m} / \mathrm{z})$ 588.35 .

\subsection{Preparation of a nitro-indol-steroid derivative.}

Finally, a nitro-indol-steroid derivative (compound 6) was synthesized via the reaction of 5 with phenylhydrazine in the presence of acetic acid to form 6 (Figure 2). The ${ }^{1} \mathrm{H}$ NMR spectrum of 6 (Figure 1) showed several signals at 0.58-1.10 ppm for methyl groups bound to steroid nucleus; at 0.98 and $1.22-2.80 \mathrm{ppm}$ for steroid moiety; at $2.88 \mathrm{ppm}$ for alkyne group; at 2.92-3.00 and 3.98-4.04 ppm for 2,3-Dihydro-1H-pyrrole ring; at $3.10 \mathrm{ppm}$ for the amino group; at 3.30-4.80-6.70 and 7.00 ppm for indole ring; at 6.86-6.98 and 7.12-7.48 ppm for phenyl groups. The ${ }^{13} \mathrm{C}$ NMR spectra display chemical shifts at $12.42-19.96 \mathrm{ppm}$ for methyl groups linked to steroid nucleus; at 23.70-30.70, 35.60-56.04, 56.60-60.34 and 130.84-130.90 ppm for steroid moiety; at 31.27, 56.44, 129.16 and $143.40 \mathrm{ppm}$ for 2,3-Dihydro-1H-pyrrole ring; at 78.22-84.02 ppm for alkyne group; at 108.36-116.27, 122.24, 127.04, 128.92 and 150.20 ppm for indole ring; at 117.22, 123.40-126.98, 127.20-128.02, 129.00, 129.80-130.96 and $145.20 \mathrm{ppm}$ for phenyl groups. Finally, the mass spectrum from $\mathbf{6}$ showed a molecular ion $(\mathrm{m} / \mathrm{z}) 6.35 .35$.

\subsection{Pharmacophore evaluation.}

Several pharmacophore models have developed to describe the three-dimensional orientation adopted by the functional groups of some drugs, which could be bound to different biomolecules [43].
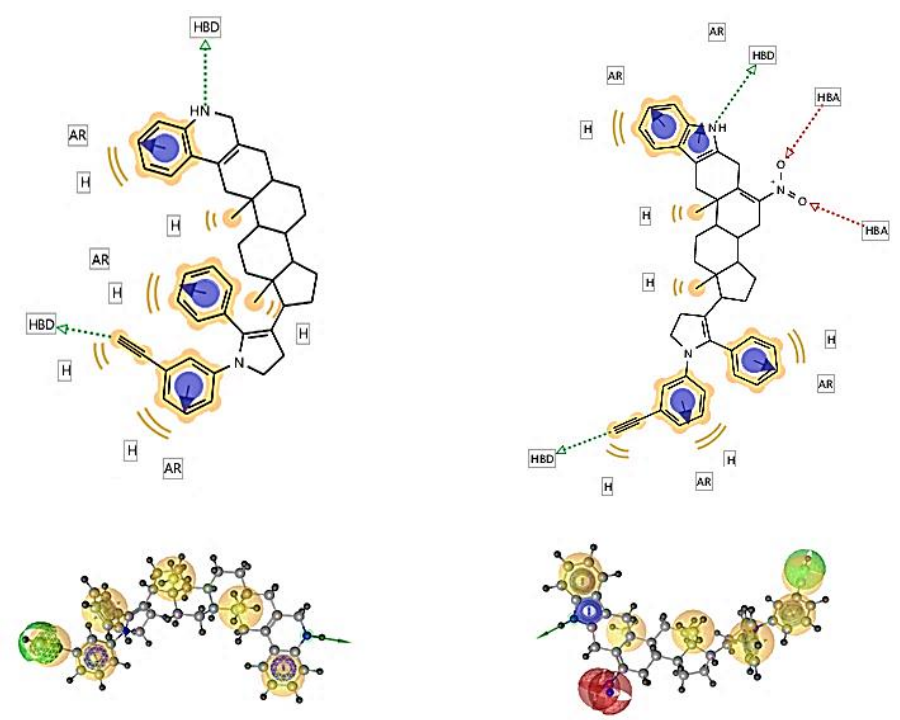

Figure 3. Pharmacophore from both compounds 3 (left) and 6 (right) using the LigandScout software. The model involves a hydrogen bond acceptor (HBA, red) and hydrogen bond donor (HBD, green).

Analyzing these data, in this investigation, the LigandScout software [29] was used to prepare a pharmacophore model for both compounds 3 and 6. The results found (Figure 3) showed that functional groups involved in the chemical structure of both compounds 3 and 6 
could interact through hydrophobic contacts or as hydrogen bond acceptors or as hydrogen bond donor with the CK2-protein surface (Table 1). However, it is essential to mention that some studies suggest that the interaction of several drugs with some proteins could be conditioned by the different types of amino acid residues involved in the protein surface [30].

Table 1. Physicochemical parameters involved in the chemical structure of both compounds 3 and 6.

\begin{tabular}{c|c|c}
\hline Parameter & Compound $3\left(\mathrm{C}_{44} \mathrm{H}_{48} \mathrm{~N}_{2}\right)$ & Compound $6\left(\mathrm{C}_{43} \mathrm{H}_{43} \mathrm{~N}_{3} \mathrm{O}_{2}\right)$ \\
\hline cLogP & 10.84 & 10.04 \\
\hline TPSA & 20.72 & 72.53 \\
\hline HBA & 0 & 2 \\
\hline HBD & 2 & 2 \\
\hline
\end{tabular}

\subsection{Protein-ligand interaction.}

There are studies that indicate that CK2 protein can be the target of several drugs [44]. To predict these interactions, some methods have been used, such as Autodock [45], Dock 6.1 [46], Dockingserver [47], and others. Analyzing these data in this study, the theoretical interaction of both compounds 3 and 6 with CK2-protein surface was evaluated using both 3FL5-protein and quinalizarin (an CK2-inhibitor) [48] as theoretical tools. Furthermore, Chimerax software [31] and Achilles' blind docking server [32] were used to evaluate the interaction of both compounds 3 and 6 with the 3FL5-protein surface. The results showed a different type of amino acid residues involved in the interaction of quinalizarin and both compounds 3 and 6 with 3FL5-protein surface (Figures 4 and 5; Tables 2-7); it is noteworthy that probably the Arg47 aminoacid residue could interact with the amino group of indole for compound 3 via a hydrogen bond. Furthermore, the Val45 aminoacid residue could interact with both amino and nitro groups through a hydrogen bond for compound 6 . These phenomena could be translated as low activation energy $(-9.80 \mathrm{Kcal} / \mathrm{mol})$ for compound 3 compared with $6(-9.20 \mathrm{Kcal} / \mathrm{mol})$ and quinalizarin $(-6.80 \mathrm{Kcal} / \mathrm{mol})$. All these data suggest that both compounds 3 and 6 could induce greater changes in the biological activity of CK2-protein compared with quinalizarin.

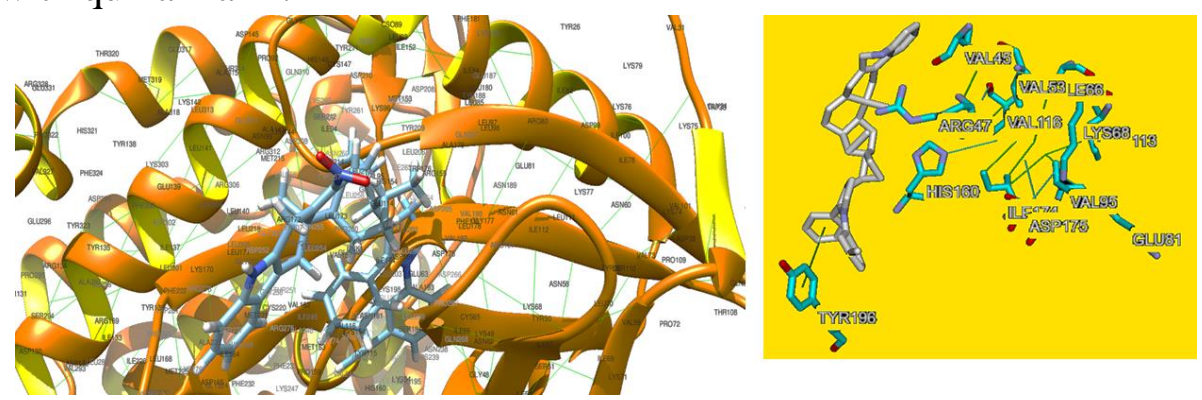

Figure 4. Interaction of compound 3 with 3FL5-protein surface using Chimerax software (left) and Achilles blind docking server (right).

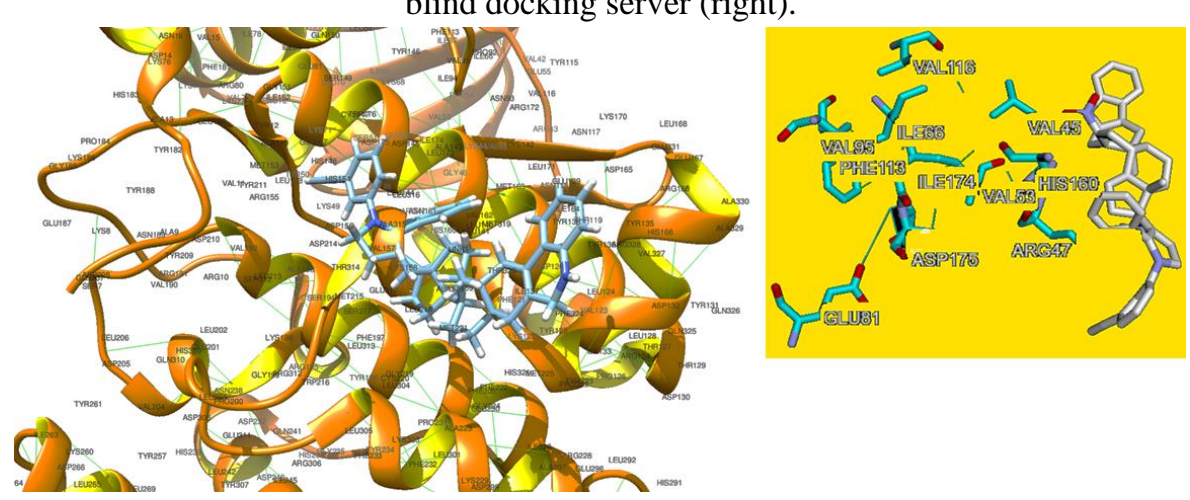

Figure 5. Binding of compound 6 with 3FL5-protein surface using Chimerax software (left) and Achilles blind docking server (right). 
Table 2. Interaction of hydrophobic involved between compound $\mathbf{3}$ and CK2 protein.

\begin{tabular}{c|c|c}
\hline Aminoacid residue & Ligand Carbon & Distance \\
\hline Lys 44 & 35 & 3,69 \\
\hline Phe $121_{12}$ & 42 & 3.64 \\
\hline Pro 159 & 43 & 3.74 \\
\hline Tyr $_{196}$ & 8 & 3.55 \\
\hline Tyr $196_{19}$ & 6 & 3.62 \\
\hline Phe $_{197}$ & 44 & 3.95 \\
\hline Phe $_{197}$ & 43 & 3.56 \\
\hline
\end{tabular}

Table 3. Hydrogen bonds of compound 3 and CK2 protein (3FL5).

\begin{tabular}{c|c|c|c}
\hline Aminoacid residue & Distance H-A & Distance D-A & Don angle \\
\hline $\operatorname{Arg}_{47}$ & 2.15 & 2.01 & 121.43 \\
\hline
\end{tabular}

Table 4. Interaction of hydrophobic involved between compound 6 and CK2 protein surface (3FL5).

\begin{tabular}{c|c|c}
\hline Aminoacid residue & Ligand Carbon & Distance \\
\hline Lys 49 & 5 & 3.96 \\
\hline Phe $_{121}$ & 43 & 3.21 \\
\hline Phe $_{121}$ & 22 & 3.34 \\
\hline Lys $_{158}$ & 45 & 3.36 \\
\hline Pro159 $_{159}$ & 44 & 3.82 \\
\hline Tyr $_{196}$ & 9 & 3.54 \\
\hline
\end{tabular}

Table 5. Hydrogen bonds of compound 6 and CK2 protein surface (3FL5).

\begin{tabular}{c|c|c|c}
\hline Aminoacid residue & Distance H-A & Distance D-A & Don angle \\
\hline Val $_{45}$ & 2.15 & 2.81 & 121.43 \\
\hline
\end{tabular}

Table 6. Interaction of hydrophobic involved between quinalizarin and CK2 protein surface.

\begin{tabular}{c|c|c}
\hline Aminoacid residue & Ligand Carbon & Distance \\
\hline Leu $_{249}$ & 1 & 3.29 \\
\hline $\mathrm{Val}_{256}$ & 13 & 3.10 \\
\hline $\mathrm{Tyr}_{307}$ & 6 & 3.07 \\
\hline
\end{tabular}

Table 7. Hydrogen bonds of compound quinalizarin and CK2 protein surface (3FL5).

\begin{tabular}{c|c|c|c}
\hline Aminoacid residue & Distance H-A & Distance D-A & Don angle \\
\hline Leu $_{249}$ & 3.47 & 3.90 & 109.02 \\
\hline $\operatorname{Arg}_{278}$ & 2.35 & 2.81 & 106.65 \\
\hline $\operatorname{Arg}_{278}$ & 3.34 & 3.70 & 102.43 \\
\hline $\operatorname{Tyr}_{307}$ & 2.93 & 3.40 & 109.31 \\
\hline Asp $308_{\text {Asp }_{308}}$ & 3.20 & 4.00 & 144.59 \\
\hline
\end{tabular}

\subsection{Pharmacokinetic evaluation.}

There are several studies to evaluate some pharmacokinetic parameters of several drugs using theoretical models such as PKQuest [49], PharmPK [50, 51] Gitub [52], SwissADME [33]. In this way, in this study, some pharmacokinetic parameters involved in both compounds 3 and 6 were evaluated using SwissADME software. The results showed in Table 8 indicate that these compounds could have low gastrointestinal absorption and, consequently, low metabolism exerted by the cytochrome P450 system. These data suggest that these compounds should be administered using other vias in some biological models, such as happening with other drugs [52].

Table 8. Pharmacokinetic parameters.

\begin{tabular}{l|l|l}
\hline Parameter & Compound 3 & Compound 6 \\
\hline GI absortion & Low & Low \\
\hline BBB permeant & No & No \\
\hline Pg-substrate & No & No \\
\hline CYP1A2 & No & No \\
\hline CYP2C19 & No & No \\
\hline CYP2C9 & No & No \\
\hline CYP2D6 & No & No \\
\hline CYP3A4 & No & No \\
\hline Log K $($ skyn permeation) & $-2.65 \mathrm{~cm} / \mathrm{seg}$ & $-3.18 \mathrm{~cm} / \mathrm{seg}$ \\
\hline https://biointerfaceresearch.com/ & &
\end{tabular}




\section{Conclusions}

In this study, the facile synthesis of two indol-steroid derivatives using several chemical strategies is reported. In addition, Theoretical analysis of the interaction between two indolsteroid derivatives showed a higher affinity of compounds 3 and $\mathbf{6}$ by the 3FL5 protein compared with quinalizarin, which is translated as a possible inhibition of the biological activity of CK2 protein.

\section{Funding}

This research received no external funding.

\section{Acknowledgments}

To Benjamin Valverde and Raquel Anzurez, for your unconditional support on this manuscript.

\section{Conflicts of Interest}

The authors declare no conflict of interest.

\section{References}

1. Siegel, R.L.; Miller, K.D.; Jemal, A. Cancer statistics, 2019. CA: A Cancer Journal for Clinicians 2019, 69, 7-34, https://doi.org/10.3322/caac.21551.

2. Samstein, R.M.; Lee, C.-H.; Shoushtari, A.N.; Hellmann, M.D.; Shen, R.; Janjigian, Y.Y.; Barron, D.A.; Zehir, A.; Jordan, E.J.; Omuro, A.; Kaley, T.J.; Kendall, S.M.; Motzer, R.J.; Hakimi, A.A.; Voss, M.H.; Russo, P.; Rosenberg, J.; Iyer, G.; Bochner, B.H.; Bajorin, D.F.; Al-Ahmadie, H.A.; Chaft, J.E.; Rudin, C.M.; Riely, G.J.; Baxi, S.; Ho, A.L.; Wong, R.J.; Pfister, D.G.; Wolchok, J.D.; Barker, C.A.; Gutin, P.H.; Brennan, C.W.; Tabar, V.; Mellinghoff, I.K.; DeAngelis, L.M.; Ariyan, C.E.; Lee, N.; Tap, W.D.; Gounder, M.M.; D’Angelo, S.P.; Saltz, L.; Stadler, Z.K.; Scher, H.I.; Baselga, J.; Razavi, P.; Klebanoff, C.A.; Yaeger, R.; Segal, N.H.; Ku, G.Y.; DeMatteo, R.P.; Ladanyi, M.; Rizvi, N.A.; Berger, M.F.; Riaz, N.; Solit, D.B.; Chan, T.A.; Morris, L.G.T. Tumor mutational load predicts survival after immunotherapy across multiple cancer types. Nature Genetics 2019, 51, 202-206, https://doi.org/10.1038/s41588-018-0312-8.

3. Waks, A.G.; Winer, E.P. Breast Cancer Treatment: A Review. Jama 2019, 321, 288-300, https://doi.org/10.1001/jama.2018.19323.

4. Im, S.A.; Lu, Y.S.; Bardia, A.; Harbeck, N.; Colleoni, M.; Franke, F.; Chow, L.; Sohn, J.; Lee, K.S.; CamposGomez, S.; Villanueva-Vazquez, R.; Jung, K.H.; Chakravartty, A.; Hughes, G.; Gounaris, I.; RodriguezLorenc, K.; Taran, T.; Hurvitz, S.; Tripathy, D. Overall Survival with Ribociclib plus Endocrine Therapy in Breast Cancer. N Engl J Med 2019, 381, 307-316, https://doi.org/10.1056/NEJMoa1903765.

5. Seldin, D.; Leder, P. Casein kinase II alpha transgene-induced murine lymphoma:relation to theileriosis in cattle. Science 1995, 267, 894-897, https://doi.org/10.1126/science.7846532.

6. Channavajhala, P.; Seldin, D.C. Functional interaction of protein kinase CK2 and c-Myc in lymphomagenesis. Oncogene 2002, 21, 5280-5288, https://doi.org/10.1038/sj.onc.1205640.

7. Miyata, Y.; Nishida, E. CK2 controls multiple protein kinases by phosphorylating a kinase-targeting molecular chaperone, Cdc37. Mol Cell Biol 2004, 24, 4065-4074, https://doi.org/10.1128/mcb.24.9.40654074.2004.

8. Romieu-Mourez, R.; Landesman-Bollag, E.; Seldin, D.C.; Traish, A.M.; Mercurio, F.; Sonenshein, G.E. Roles of IKK kinases and protein kinase CK2 in activation of nuclear factor-kappaB in breast cancer. Cancer Res 2001, 61, 3810-3818.

9. Song, D.H.; Sussman, D.J.; Seldin, D.C. Endogenous protein kinase CK2 participates in Wnt signaling in mammary epithelial cells. J Biol Chem 2000, 275, 23790-23797, https://doi.org/10.1074/jbc.M909107199.

10. Song, D.H.; Dominguez, I.; Mizuno, J.; Kaut, M.; Mohr, S.C.; Seldin, D.C. CK2 phosphorylation of the armadillo repeat region of beta-catenin potentiates Wnt signaling. J Biol Chem 2003, 278, 24018-24025, https://doi.org/10.1074/jbc.M212260200.

11. Ponce, D.P.; Yefi, R.; Cabello, P.; Maturana, J.L.; Niechi, I.; Silva, E.; Galindo, M.; Antonelli, M.; Marcelain, K.; Armisen, R.; Tapia, J.C. CK2 functionally interacts with AKT/PKB to promote the $\beta$-catenindependent expression of survivin and enhance cell survival. Molecular and Cellular Biochemistry 2011, 356, https://doi.org/10.1007/s11010-011-0965-4. 
12. Uematsu, K.; He, B.; You, L.; Xu, Z.; McCormick, F.; Jablons, D.M. Activation of the Wnt pathway in non small cell lung cancer: evidence of dishevelled overexpression. Oncogene 2003, 22, 7218-7221, https://doi.org/10.1038/sj.onc.1206817.

13. Morin, P.J.; Sparks, A.B.; Korinek, V.; Barker, N.; Clevers, H.; Vogelstein, B.; Kinzler, K.W. Activation of beta-catenin-Tcf signaling in colon cancer by mutations in beta-catenin or APC. Science 1997, 275, 17871790, https://doi.org/10.1126/science.275.5307.1787.

14. Fernández, J.G.; Rodríguez, D.A.; Valenzuela, M.; Calderon, C.; Urzúa, U.; Munroe, D.; Rosas, C.; Lemus, D.; Díaz, N.; Wright, M.C.; Leyton, L.; Tapia, J.C.; Quest, A.F. Survivin expression promotes VEGFinduced tumor angiogenesis via PI3K/Akt enhanced $\beta$-catenin/Tcf-Lef dependent transcription. Mol Cancer 2014, 13, 209, https://doi.org/10.1186/1476-4598-13-209.

15. Litchfield, D. Protein kinase CK2: structure, regulation and role in cellular decisions of life and death. Biochemistry Journal 2003, 369, 1-15, https://doi.org/10.1042/bj20021469.

16. Ka, S.O.; Hwang, H.P.; Jang, J.H.; Hyuk Bang, I.; Bae, U.J.; Yu, H.C.; Cho, B.H.; Park, B.H. The protein kinase 2 inhibitor tetrabromobenzotriazole protects against renal ischemia reperfusion injury. Scientific Reports 2015, 5, https://doi.org/10.1038/srep14816.

17. Hathaway, G.M.; Lubben, T.H.; Traugh, J.A. Inhibition of casein kinase II by heparin. J Biol Chem 1980, 255, 8038-8041.

18. Yim, H.; Lee, Y.H.; Lee, C.H.; Lee, S.K. Emodin, an anthraquinone derivative isolated from the rhizomes of Rheum palmatum, selectively inhibits the activity of casein kinase II as a competitive inhibitor. Planta Med 1999, 65, 9-13, https://doi.org/10.1055/s-1999-13953.

19. Cozza, G.; Mazzorana, M.; Papinutto, E.; Bain, J.; Elliott, M.; Di-Maira, G.; Battistutta, R. Quinalizarin as a potent, selective and cell-permeable inhibitor of protein kinase CK2. Biochemistry Journal 2009, 421, 387395, https://doi.org/10.1042/BJ20090069.

20. Rangasamy, L.; Ortín, I.; Zapico, J.M.; Coderch, C.; Ramos, A.; de Pascual-Teresa, B. New Dual CK2/HDAC1 Inhibitors with Nanomolar Inhibitory Activity against Both Enzymes. ACS Medicinal Chemistry Letters 2020, 11, 713-719, https://doi.org/10.1021/acsmed chemlett.9b00561.

21. Dowling, J.E.; Chuaqui, C.; Pontz, T.W.; Lyne, P.D.; Larsen, N.A.; Block, M.H.; Chen, H.; Su, N.; Wu, A.; Russell, D.; Pollard, H.; Lee, J.W.; Peng, B.; Thakur, K.; Ye, Q.; Zhang, T.; Brassil, P.; Racicot, V.; Bao, L.; Denz, C.R.; Cooke, E. Potent and Selective Inhibitors of CK2 Kinase Identified through Structure-Guided Hybridization. ACS Medicinal Chemistry Letters 2012, 3, 278-283, https://doi.org/10.1021/ml200257n.

22. Cozza, G.; Pinna, L.A.; Moro, S. Protein kinase CK2 inhibitors: a patent review. Expert Opinion on Therapeutic Patents 2012, 22, 1081-1097, https://doi.org/10.1517/13543776.2012.717615.

23. Morshed, M.N.; Muddassar, M.; Pasha, F.A.; Cho, S.J. Pharmacophore identification and validation study of CK2 inhibitors using CoMFA/CoMSIA. Chem Biol Drug Des 2009, 74, 148-158, https://doi.org/10.1111/j.1747-0285.2009.00841.x.

24. Haidar, S.; Bouaziz, Z.; Marminon, C.; Laitinen, T.; Poso, A.; Le Borgne, M.; Jose, J. Development of Pharmacophore Model for Indeno[1,2-b]indoles as Human Protein Kinase CK2 Inhibitors and Database Mining. Pharmaceuticals 2017, 10, 1-13, https://doi.org/10.3390/ph10010008.

25. Di-Wu, L.; Li, L.; Wang, W.; Xie, H.; Yang, J.; Zhang, C.; Yang S. Identification of CK2 inhibitors with new scaffolds by a hybrid virtual screening approach based on Bayesian model; pharmacophore hypothesis and molecular docking. Journal of Molecular Graphics and Modelling 2012, 36, 42-47, https://doi.org/10.1016/j.jmgm.2012.03.004.

26. Sun, H.P.; Zhu, J.; Chen, F.H.; You, Q.D. Structure-Based Pharmacophore Modeling from Multicomplex: a Comprehensive Pharmacophore Generation of Protein Kinase CK2 and Virtual Screening Based on it for Novel Inhibitors. Mol Inform 2011, 30, 579-592, https://doi.org/10.1002/minf.201000178.

27. Lauro, F.-V.; Francisco, D.-C.; Marcela, R.-N.; Virginia, M.-A.; Eduardo, P.G.; Maria, L.-R.; Lenin, H.-H.; Alondra, A.-J.; Jhair, C.-T. Preparation of a steroid-oxazole-1,2'-[1,3]oxazete] derivative: biological and theoretical evaluation of its interaction with a kinase protein (CK2). SN Applied Sciences 2019, 1, https://doi.org/10.1007/s42452-019-0378-7.

28. Bowers, A.; Sánchez, M.B.; Ringold, H.J. Steroids. CIX.1 Studies in Nitro Steroids. Part 1. The synthesis of $6 \alpha-$ and $6 \beta$-Nitrotestosterone and $6 \alpha$ - and $6 \beta$-Nitroprogesterone2. Journal of the American Chemical Society 1959, 81, 3702-3706, https://doi.org/10.1021/ja01523a052.

29. Rana Adnan, T.; Sheikh Arslan, S. Pharmacoinformatics and Molecular Docking Studies Reveal Potential Novel Compounds Against Schizophrenia by Target SYN II. Combinatorial Chemistry \& High Throughput Screening 2018, 21, 175-181, https://doi.org/10.2174/1386207321666180213092018.

30. Protein Data Bank: the single global archive for 3D macromolecular structure data. Nucleic acids research 2019, 47, D520-D528, https://doi.org/10.1093/nar/gky949.

31. Goddard, T.D.; Huang, C.C.; Meng, E.C.; Pettersen, E.F.; Couch, G.S.; Morris, J.H.; Ferrin, T.E. UCSF ChimeraX: Meeting modern challenges in visualization and analysis. Protein Science 2018, 27, 14-25, https://doi.org/10.1002/pro.3235.

32. Sánchez-Linares, I.; Pérez-Sánchez, H.; Cecilia, J.M.; García, J.M. High-Throughput parallel blind Virtual Screening using BINDSURF. BMC Bioinformatics 2012, 13 Suppl 14, S13, https://doi.org/10.1186/14712105-13-s14-s13. 
33. Daina, A.; Michielin, O.; Zoete. V. SwissADME: a free web tool to evaluate pharmacokinetics, drug-likeness and medicinal chemistry friendliness of small molecules. Science Reports 2017, 7, https://doi.org/10.1038/srep42717.

34. Senadi, G.C.; Lu, T.-Y.; Dhandabani, G.K.; Wang, J.-J. Palladium-Catalyzed Double-Isocyanide Insertion via Oxidative N-O Cleavage of Acetyl Oximes: Syntheses of 2H-Pyrrol-2-imines. Organic Letters 2017, 19, 1172-1175 https://doi.org/10.1021/acs.orglett.7b00208.

35. Gao, P.; Wang, J.; Bai, Z.; Fan, M.-J.; Yang, D.-S.; Guan, Z.-H. K2S2O8/TEMPO-Induced Cascade Oxidative Cyclization/1,2-Migration of Electron-Deficient Groups: Strategy for the Construction of 1HPyrrol-2(3H)-ones. Organic Letters 2018, 20, 3627-3630, https://doi.org/10.1021/acs.orglett.8b01402.

36. Ouyang, X.-H.; Song, R.-J.; Liu, Y.; Hu, M.; Li, J.-H. Copper-Catalyzed Radical [2 + $2+1]$ Annulation of Benzene-Linked 1,n-Enynes with Azide: Fused Pyrroline Compounds. Organic Letters 2015, 17, 60386041, https://doi.org/10.1021/acs.orglett.5b03040.

37. del Corte, X.; Maestro, A.; Vicario, J.; Martinez de Marigorta, E.; Palacios, F. Brönsted-Acid-Catalyzed Asymmetric Three-Component Reaction of Amines, Aldehydes, and Pyruvate Derivatives. Enantioselective Synthesis of Highly Functionalized $\gamma$-Lactam Derivatives. Organic Letters 2018, 20, 317-320, https://doi.org/10.1021/acs.orglett.7b03397.

38. Ying, J.; Fu, L.-Y.; Zhong, G.; Wu, X.-F. Cobalt-Catalyzed Direct Carbonylative Synthesis of Free (NH)Benzo[cd]indol-2(1H)-ones from Naphthylamides. Organic Letters 2019, 21, 5694-5698, https://doi.org/10.1021/acs.orglett.9b02037.

39. Peng, H.; Ma, J.; Duan, L.; Zhang, G.; Yin, B. CuH-Catalyzed Synthesis of 3-Hydroxyindolines and 2-Aryl$3 \mathrm{H}$-indol-3-ones from o-Alkynylnitroarenes, Using Nitro as Both the Nitrogen and Oxygen Source. Organic Letters 2019, 21, 6194-6198, https://doi.org/10.1021/acs.orglett.9b01849.

40. Wang, Z.J.; Yang, J.G.; Yang, F.; Bao, W. One-Pot Synthesis of Pyrimido[1,6-a]indol-1(2H)-one Derivatives by a Nucleophilic Addition/Cu-Catalyzed N-Arylation/Pd-Catalyzed C-H Activation Sequential Process. Organic Letters 2010, 12, 3034-3037, https://doi.org/10.1021/ol101041e.

41. Jia, S.; Dong, G.; Ao, C.; Jiang, X.; Hu, W. Rhodium-Catalyzed Formal C-O Insertion in Carbene/Alkyne Metathesis Reactions: Synthesis of 3-Substituted 3H-Indol-3-ols. Organic Letters 2019, 21, 4322-4326, https://doi.org/10.1021/acs.orglett.9b01492.

42. Mukai, C.; Yoshida, T.; Sorimachi, M.; Odani, A. Co2(CO)8-Catalyzed Intramolecular HeteroPauson-Khand Reaction of Alkynecarbodiimide: Synthesis of $( \pm)$-Physostigmine. Organic Letters 2006, 8 , 83-86, https://doi.org/10.1021/ol052562z,

43. Sun, H.P.; Zhu, J.; Chen, F.H.; You, Q.D. Structure-Based Pharmacophore Modeling from Multicomplex: a Comprehensive Pharmacophore Generation of Protein Kinase CK2 and Virtual Screening Based on it for Novel Inhibitors. Mol Inform 2011, 30, 579-592, https://doi.org/10.1002/minf.201000178.

44. Cozza, G. The development of CK2 inhibitors: From traditional pharmacology to in silico rational drug design. Pharmaceuticals 2017, 10, 1-23, https://doi.org/10.3390/ph10010026.

45. Srivastava, R.; Akthar, S.; Sharma, R.; Mishra, S. Identification of Ellagic acid analogues as potent inhibitor of protein Kinase CK2:A chemopreventive role in oral cancer. Bioinformation 2015, 11, 21-26, https://doi.org/10.6026/97320630011021.

46. López-Ramos, M.; Prudent, R.; Moucadel, V.; Sautel, C.F.; Barette, C.; Lafanechère, L.; Mouawad, L.; Grierson, D.; Schmidt, F.; Florent, J.-C.; Filippakopoulos, P.; Bullock, A.N.; Knapp, S.; Reise, J.-B.; Cochet, C. New potent dual inhibitors of CK2 and Pim kinases: discovery and structural insights. The FASEB Journal 2010, 24, 3171-3185, https://doi.org/10.1096/fj.09-143743.

47. Figueroa-Valverde, L.; Diaz-cedillo, F.; Rosas-Nexticapa, M.; Lopez-Ramos, M.; Mateu-Armand, V, Garcimarrero, E.; Cauich, R. Design and Synthesis of two imidazole derivative: theorethical evaluation of interaction with a coronavirus (HCoV-NL63). Biointerface Research in Applied Chemistry. 2020, 10, 58695874. https://doi.org/10.33263(BRLAC.104.869874.

48. Franchin, C.; Cesaro, L.; Salvi, M.; Millioni, R.; Iori, E.; Cifani, P.; James, P.; Arrigoni, G.; Pinna, L. Quantitative analysis of a phosphoproteome readily altered by the protein kinase CK2 inhibitor quinalizarin in HEK-293T cells. Biochimica et Biophysica Acta (BBA) - Proteins and Proteomics 2015, 1854, 609-623, https://doi.org/10.1016/j.bbapap.2014.09.017.

49. Levitt, D.G. PKQuest_Java: free, interactive physiologically based pharmacokinetic software package and tutorial. BMC Res Notes 2009, 2.

50. Ishaku, S.; Bakare-Odunola, M.; Musa, A.; Yakasai, I.; Garba, M.; Adzu, B. Evaluating the effect of artesunate on the pharmacokinetics of gliclazide in diabetic subjects. International Journal of Biological and Chemical Sciences 2019, 13, 2104-2111.

51. Guerra, R.P.; Carvalho, A.M.; Mateus, P. Model selection for clustering of pharmacokinetic responses. Computer Methods and Programs in Biomedicine 2018, 162, 11-18, https://doi.org/10.1016/j.cmpb.2018.05.002.

52. Briasoulis, E.; Pavlidis, N.; Terret, C.; Bauer, J.; Fiedler, W.; Schöffski, P.; Raoul, J.L.; Hess, D.; Selvais, R.; Lacombe, D.; Bachmann, P.; Fumoleau, P. Glufosfamide administered using a 1-hour infusion given as first-line treatment for advanced pancreatic cancer. A phase II trial of the EORTC-new drug development group. European Journal of Cancer 2003, 39, 2334-2340, https://doi.org/10.1016/S0959-8049(03)00629-4. 